\title{
TERRORIST ATTACKS AND CORPORATE INVESTMENT IN INDONESIA
}

\author{
Dat Thanh Nguyen*, Dinh Hoang Bach Phan** and Van Ky Long Nguyen*** \\ * Corresponding author. Banking Department, University of Economics - The University of Danang, \\ Vietnam. Email: datnt@due.udn.vn \\ ** Department of Economics, Finance, and Marketing, La Trobe University, Australia. \\ *** FPT University, Vietnam
}

\begin{abstract}
Using yearly data from 1997 to 2017, this paper studies the effect of terrorism (number of attacks) on corporate investment in Indonesia. Applying an investment-type model, we show that firms reduce their capital expenditure due to an increase in the number of terrorist attacks. On average, a one standard deviation increase in the number of terrorist attacks reduces corporate investment by $9.23 \%$. We also find heterogenous reactions of firms to terrorism across different sectors and different panels based on firm characteristics. Finally, our main results remain consistent after performing several robustness tests.
\end{abstract}

Keywords: Terrorism; Corporate investment; Sectoral analysis; Firm characteristics; Economic significance.

JEL Classifications: G31.

Article history:

Received : February 26, 2020

Revised : June 17, 2020

Accepted : November 27, 2020

Available Online: March 31, 2021

https://doi.org/10.21098/bemp.v24i1.1283 


\section{INTRODUCTION}

Terrorism is of great concern as it disrupts economic growth and development in general. It has undeniable negative effects, such as loss of human life and property destruction. Besides these effects, terrorist attacks adversely affect economic outlook and financial markets through reduced consumer and investor confidence (see Johnston and Nedelescu, 2006; Frey et al., 2007). A prime example is the attack in Bali in 2002, which killed 202 people. This attack disrupted the Indonesian economy. The stock market, for example, plunged $10.4 \%$, the rupiah fell significantly against the dollar and many industries suffered losses, both directly and indirectly, due to the loss of consumer and investor confidence (Bradsher and Banerjee, 2002).

Due to the prevalence of terrorism in recent years, a growing literature has been devoted to studying the effect of terrorism on the economic and financial systems. These studies focus on: macroeconomic variables (Abadie and Gardeazabal, 2003; Eckstein and Tsiddon, 2004; Blomberg et al., 2004; Nitsch and Schumacher, 2004; Llussa and Tavares, 2011; Narayan et al., 2018); stock prices (Eldor and Melnick, 2004; Karolyi and Martell, 2005) and stock market returns (Carter and Simkins, 2004; Drakos, 2004; Ito and Lee, 2005; Arin et al., 2008; Chesney et al., 2011; Goel et al., 2017); and stock market sentiment (Burch et al., 2003; Glaser and Webber, 2005; Nikkinen, and Vahamaa, 2010).

Regarding the literature on the effect of uncertainty on investment, there are studies that identify types (namely, input and output price uncertainty) of uncertainty that can potentially impact investment (see Pindyck, 1991; Bloom et al., 2007). Other studies also point out macroeconomic uncertainty (Bloom, 2009), policy uncertainty (Gulen and Ion, 2015; Setiastuti, 2017), political uncertainty (Julio and Yook, 2011, 2012; An et al., 2016) and oil price uncertainty (Uri, 1980; Bernanke, 1983; Mohn and Misund, 2009; Elder and Serletis, 2010a, 2010b; Henriques and Sadorsky, 2011, Wang et al., 2017; Phan et al., 2019) as important to determining investment. ${ }^{1}$

In Indonesia, terrorism is also a matter of great concern. According to the 2019 Global Terrorism Index, Indonesia ranks $35^{\text {th }}$ among countries with a high index score. In terms of the deaths from terrorism during 2017-2019, Indonesia ranks $5^{\text {th }}$. Among the Asia-Pacific countries that have been consistently affected by terrorism, Indonesia is the only one with an index score that deteriorated in 2018. Looking at Figure 1, which plots the number of terrorist attacks in the country from 1999 to 2017, we observe a worrying trend. Although the number of attacks dropped significantly from over 100 cases in 2001 to only 2 in 2007, the number of terrorist incidents started to increase again, which averaged 20 cases per year from 2007 to 2019.

\footnotetext{
1 Some recent papers investigate the uncertainty by COVID-19 on financial markets, such as AlAwadhi et al. (2020), Ali et al. (2020), Devpura (2020), Fang \& Zhang (2021), Fu \& Shen (2020), GilAlana \& Monge (2020), Haroon \& Rizvi (2020), Hoang \& Syed (2021), Liu et al. (2020), Narayan (2020a, b, c), Qin et al. (2020), Phan \& Narayan (2020), Narayan et al. (2021), Sha \& Sharma (2020), Sharma \& Sha (2020), Sharma (2020), Zhang et al. (2020), Wang \& Su (2021). See also recent survey paper by
} 
Figure 1.

Terrorist Attacks and Corporate Investment in Indonesia

This figure plots the number of terrorist attacks (right axis) and the average of corporate investments (left axis) in Indonesia from 1999-2017

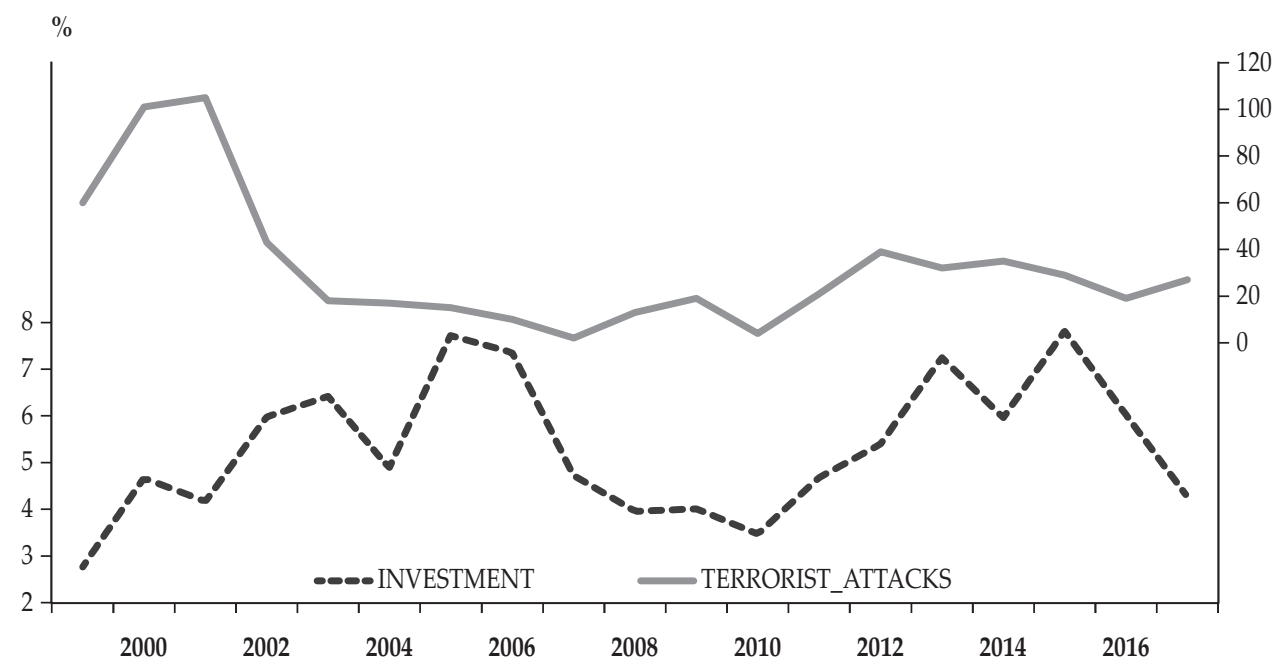

This paper aims to empirically examine the relationship between terrorist attacks and investment decision at the corporate level in Indonesia. In particular, we aim to answer the following question: Does terrorism negatively influence Indonesian firm operations, especially investment activities? The answer to this question is of particular importance as terrorism can affect firms in various industries both directly and indirectly.

The underlying rationale of this hypothesis is simple. Because terrorist attacks are unforeseen catastrophic events, terrorism is believed to have a strong adverse impact on market sentiment and significantly increase uncertainty (Nikkinen and Vahamaa, 2010). The effect of uncertainties caused by terrorism on corporate investment can be explained by two strands of the literature. First, the real option theory suggests that faced with surging uncertainty, firms may choose to postpone their investment and wait for new information (see Bernanke, 1983; McDonald and Siegel, 1986; and Pindyck, 1988, 1991). Moreover, terrorism can also affect corporate investment via the demand channel as it lowers consumer and investor confidence. As a result, there may be a shock to firms' demand which induces firms to become more cautious and reduce their irreversible investment (Bloom et al., 2007). The second strand of the literature is motivated by financial frictions theory. The risk of default, as well as the equity risk premium, are arguably increased by uncertainty (see Greenwald and Stiglitz, 1990; Gilchrist et al., 2011. This, in turn, increases the cost of external financing and hence reduces firm investment level.

We test the relationship between terrorism and corporate investment using a data set which includes around 5000 firm-year observations from 1997 until 2017. Our study contributes to the terrorism and corporate investment literature in the following ways. 
First, whilst a lot of attention has been given to the effect of terrorism on investment at the aggregate level, such as national private investment (Abadie and Gardeazabal, 2003; Eckstein and Tsiddon, 2004; Blomberg et al., 2004; Nitsch and Schumacher, 2004; Llussa and Tavares, 2011), foreign direct investment (Enders and Sandler, 1996) or at the industry level, such as farming (Singh, 2013) and tourism (Choyakh, 2008), our understanding of the effect of terrorism on investment at the firm level is limited. One notable exception is Oh and Oetzel (2011). Oh and Oetzel (2011) employ a data set of 71 multinational corporations in Europe from 2001 to 2006 with 31,285 observations to study the effect of major disasters on subsidiary investment levels of these corporations. They discover that terrorist attacks have a negative impact on the number of foreign subsidiaries of these multinational firms. This study aside, none consider the effect of terrorism on a firm's capital expenditure. Therefore, we contribute to the literature by presenting the first evidence on this relationship at the firm level.

Second, we provide a broader picture of the impact of terrorism on corporate investment by examining this relationship across different industries, namely basic materials (BM), consumer discretion (CD), consumer staples (CS), energy (EN), financials (FI), health care (HC), industrials (IN), real estate (RE), technology (TE), and telecommunications (TEL). Moreover, we also examine whether the effect of terrorism on corporate investment is subject to firm characteristics. To do this, we divide our sample into different panels, including low market capitalization (MV0), high market capitalization (MV1), low book-to-market ratio (BM0), high book-to-market ratio (BM1), young firms (FA0), mature firms (FA1), low trading volume (TV0), high trading volume (TV1), low volatility (VO0), and high volatility (VO1).

Our findings are as follows. First, we document a negative impact of terrorism on corporate investment (capital expenditure) in Indonesia. Second, both the sign and size of the effect of terrorism on firm investment vary across different sectors as well as across different firm characteristics. Finally, our main results hold under some robustness tests, including using different model specifications and different sub-sample periods.

The remainder of this paper is structured as follows. Section II describes the data set used for our analysis and the empirical model. Section III presents the main findings and robustness tests. Finally, the paper is concluded in section IV.

\section{DATA AND METHODOLOGY}

\section{A. Data}

Table 1 provides specific details of the variables used in this study. All firm-specific data were downloaded from Datastream, while Indonesia's GDP growth rate and the number of terrorist attacks in Indonesia were collected from the World Bank and Global Terrorism database, respectively. Our sample has annual data that start from 1999 and end in 2017. 
Table 1.

\section{Variables Description}

This table reports the description and data source of variables

\begin{tabular}{lcc}
\hline Variable & Description & Database \\
\hline INV & Capital expenditure scaled by total assets in a previous year & Datastream \\
TERRORISM & Natural log of the number of terrorist attacks in Indonesia & $\begin{array}{c}\text { Global Terrorism } \\
\text { Database }\end{array}$ \\
$Q$ & $\begin{array}{c}\text { Ratio of the market value of assets to the book value of assets } \\
\text { Earnings before interest and taxes minus taxes and interest }\end{array}$ & Datastream \\
CF & expense plus depreciation and amortization, scaled by total & Datastream \\
GDP & assets & World Bank \\
GROWTH & Indonesia GDP growth rate & Datastream \\
LEVERAGE & Change in sales scaled by sales of the previous year. & Datastream \\
\hline
\end{tabular}

To gain more insights on the hypothesis test, we group our sample into various panels based on their sectors and firm characteristics. First, we have an aggregate panel that includes all firms in our sample. For sectoral analysis, the dataset is portioned into 10 sectors and 10 panels formed on firm characteristics, as explained above.

\section{B. Methodology}

Our main regression follows a typical investment type model specification:

$$
I N V_{i, t}=\alpha+\beta_{1} \text { TERRORISM }_{t}+\beta_{2} Q_{i, t-1}+\beta_{3} C F_{i, t}+\beta_{4} G D P_{t-1}+\varepsilon_{i, t}
$$

where $i$ and $t$ are index firm and time, respectively. This regression model follows previous studies, such as Blundell et al. (1992), Blundell et al. (1999), Agung (2000), Hidayat (2010), Julio and Yook (2012), Henriques and Sadorsky (2011) and Phan et al. (2019). Our dependent variable, $I N V$, is defined as the firm's capital expenditure as a percentage of total assets in the previous year. The main independent variable, TERRORISM, is measured by the natural log of the number of terrorist attacks in Indonesia. $Q$ is the Tobin's $q$, which is measured by the asset market value to book value, in ratio form. Cashflow, CF, is earnings before interest and taxes, minus interest and tax expenses, plus depreciation and amortization. Following the previous literature (see Julio and Yook, 2012; Gulen and Ion, 2015; Phan et al., 2019), we control for general economic conditions by using the growth rate of GDP. As conventional practices, a panel data model with fixed firm and year effects are used, and the standard errors are clustered at the firm level.

\section{EMPIRICAL RESULTS}

\section{A. Preliminary Results}

Table 2 reports some selected descriptive statistics, including the number of observations, mean, median, standard deviation, $25^{\text {th }}$ percentile and $75^{\text {th }}$ percentile 
values. Consider the third column of Table 2, where we report the mean values. The Indonesian firms, on average, spend an amount valued about $5.589 \%$ of prior year's total assets on their capital expenditure. During the period from 1999 to 2017 , the yearly average number of terrorist attacks in Indonesia is 23.67. The mean values of $Q$ and $C F$ are 2.008 and 10.098, respectively. In term of GDP, Indonesia experienced an average growth rate of $5.043 \%$ per year during the sample period. GROWTH and LEVERAGE are the two variables that are used later in our robustness tests. While the former is measured by the sales growth rate, which is the change in sales scaled by sales in the previous year, the latter is firm leverage ratio measured by the ratio of total debt to total assets. In the 1999-2017 period, Indonesian firms had a high sales growth rate, which averaged $12.06 \%$ per annum. Finally, the average leverage ratio of Indonesian firms during this period is 0.284 .

Table 2

Descriptive Statistics

This table reports selected descriptive statistics for the variables.

\begin{tabular}{lcccccc}
\hline Variable & Observation & Mean & Median & Std. Dev. & 25th & 75th \\
\hline INV $(\%)$ & 5774 & 5.589 & 2.376 & 8.631 & 0.539 & 6.760 \\
TERRORISM & 7942 & 3.164 & 3.091 & 0.864 & 2.773 & 3.689 \\
$Q$ & 5620 & 2.008 & 1.120 & 3.291 & 0.590 & 2.218 \\
CF $(\%)$ & 5751 & 10.098 & 9.256 & 12.620 & 3.630 & 15.713 \\
GDP $(\%)$ & 7942 & 5.043 & 5.033 & 1.209 & 4.780 & 6.014 \\
GROWTH $(\%)$ & 5765 & 12.060 & 11.230 & 38.003 & -1.296 & 24.042 \\
LEVERAGE & 6072 & 0.284 & 0.215 & 0.298 & 0.047 & 0.426 \\
\hline
\end{tabular}

Next, we turn to Table 3, which reports results of the unconditional correlations among variables in our main regression model. Note that the correlation coefficients are quite low, except the one between GDP and TERRORISM, which is -0.584. However, it is still acceptable, and we can safely infer that our model is free from the multicollinearity problem.

Table 3.

Unconditional Correlation

This table reports the unconditional correlations and their $p$-values (in parentheses) among variables in our regression model.

\begin{tabular}{lcccc}
\hline & INV & TERRORISM & $Q$ & CF \\
\hline TERRORISM & $-0.038^{* * *}$ & & & \\
& $(0.004)$ & & & \\
$Q$ & $0.132^{* * *}$ & $-0.043^{* * *}$ & & \\
CF & $(0.000)$ & $(0.001)$ & & \\
& $0.218^{* * *}$ & $-0.064^{* * *}$ & $0.245^{* * *}$ & \\
GDP & $(0.000)$ & $(0.000)$ & $(0.000)$ & \\
& $0.118^{* * *}$ & $-0.584^{* * *}$ & $0.033^{* * *}$ & 0.009 \\
& $(0.000)$ & $(0.000)$ & $(0.012)$ & $(0.481)$ \\
\hline
\end{tabular}




\section{B. Regression Results}

B1. Aggregate Panel

We report the results of the determinants of corporate investment in Table 4 . The second column of Table 4 presents value coefficients and standard errors of our main regression, while the third column presents results without TERRORISM. The results can be summarized as follows. First, the coefficient of the terrorist attack variable is negative (-0.597), which means that if the number of attacks increase by $1 \%$ then firms will reduce their capital expenditure - total assets ratio by 0.597 basis points. This result supports our hypothesis that terrorism, measured by the number of attacks, has a negative impact on corporate investment. In other words, firms tend to invest less in response to an increase in the number of terrorist attacks in Indonesia. This result is also statistically significant.

Furthermore, we examine the effects of other determinants, such as $Q, C F$ and growth rate of GDP. As per our expectations, the results from both regressions (1) and (2) show that the coefficients of these variables are statistically significant and have consistent signs across the two models. Finally, the adjusted $R$-squared in both regressions takes a value of $33.3 \%$.

Table 4.

\section{Regression Results}

This table reports the results of determinants of corporate investments with and without terrorist attack variable in Model (1) and (2), respectively. The regression models take the following forms:

$I N V_{i, t}=\alpha+\beta_{1}$ TERRORISM $_{t}+\beta_{2} Q_{i, t-1}+\beta_{3} C F_{i, t}+\beta_{4} G D P_{t-1}+\varepsilon_{i, t}$

$I N V_{i, t}=\alpha+\beta_{1} Q_{i, t-1}+\beta_{2} C F_{i, t}+\beta_{3} G D P_{t-1}+\varepsilon_{i, t}$

The coefficients are their $t$-statistics are reported. ${ }^{*}{ }^{* *}$, and ${ }^{* *}$ denote significance at the $10 \%, 5 \%$ and $1 \%$ levels, respectively.

\begin{tabular}{lcc}
\hline & $\mathbf{( 1 )}$ & $\mathbf{( 2 )}$ \\
\hline TERRORISM & $-0.597^{* * *}$ & \\
$Q$ & $(-7.210)$ & $0.263^{* *}$ \\
& $0.263^{* *}$ & $(2.781)$ \\
CF & $(2.781)$ & $0.032^{* * *}$ \\
GDP & $0.032^{* * *}$ & $(4.263)$ \\
& $(4.263)$ & $-0.275^{* * *}$ \\
Constant & $-0.457^{* * *}$ & $(-5.673)$ \\
& $(-11.446)$ & $3.967^{* * *}$ \\
Observations & $6.874^{* * *}$ & $(15.430)$ \\
Firm effect & $(15.879)$ & 4,854 \\
Year effect & 4,854 & Controlled \\
Adjusted $R^{2}$ & Controlled & Controlled \\
\hline
\end{tabular}

To examine the economic significance of terrorism on corporate investment, we calculate the effect of a one standard deviation increase in the number of terrorist 
attacks. On average, when the number of attacks in a year increase by one standard deviation, i.e. 0.864 , firms reduce their capital expenditure by nearly $9.23 \%{ }^{2}$

\section{B2. Sectoral Analysis}

This section investigates the effect of terrorist attack on investment of firms in different sectors. Given that corporate investment projects are partially irreversible, the effect of uncertainty is expected to be stronger for firms with a higher level of irreversible investments (see Gulen and Ion, 2015). In addition, the cost of delaying investment is expected to be different across firms and industries. Specifically, firms in more competitive industries experience lower expected costs of waiting due to the larger advantage of being the first-mover. Therefore, it is of interest to investigate the heterogeneity in the investment-terrorism relationship across different sectors. ${ }^{3}$

The regression results for each of the 10 sectors are presented in Table 5 . Results are as follows. First, the effect of terrorism on corporate investment is statistically significant in six sectors (60\%), including basic materials, consumer staples, healthcare, industrials, technology and telecommunications. Second, regarding the sign of the effect, while terrorism has a negative impact on basic materials, consumer staples, industrials and technology, it positively influences investments of firms in healthcare and telecommunications. Third, the magnitude of the effect are different across sectors. The absolute values of the terrorism coefficient are in the 2.122 to 10.150 range. Out of six panels that are statistically significant, capital expenditure of firms in the consumer staples sector is affected least by terrorism and telecommunications sector reacts most strongly to terrorism.

Similar to the previous subsection, we also calculate the economic significance of terrorism on firm investment. For those firms that react negatively to terrorism, we find that when the number of attacks decreases by one standard deviation, firms in basic materials increase their capital expenditure by $113.27 \%$ and firms in consumer staples, industrials and technology raise their investments by $32.80 \%$, $41.96 \%$ and $68.73 \%$, respectively. In contrast, a one standard deviation increase in the number of terrorist attacks leads to $101.74 \%$ and $156.91 \%$ increases in capital investment of firms in healthcare and telecommunications sectors, respectively.

Finally, the effects of other determinants, i.e. $Q, C F$ and GDP, are statistically significant in many panels, and the adjusted $R$-squared varies in the 0.174 to 0.487 range.

\footnotetext{
2 The economic significance is calculated by taking one standard deviation of TERRORISM multiply by the value of its coefficient in Model (2) of Table 4 and divide by it mean value.

3 Note that due to low number of observations, utility sector is dropped.
} 


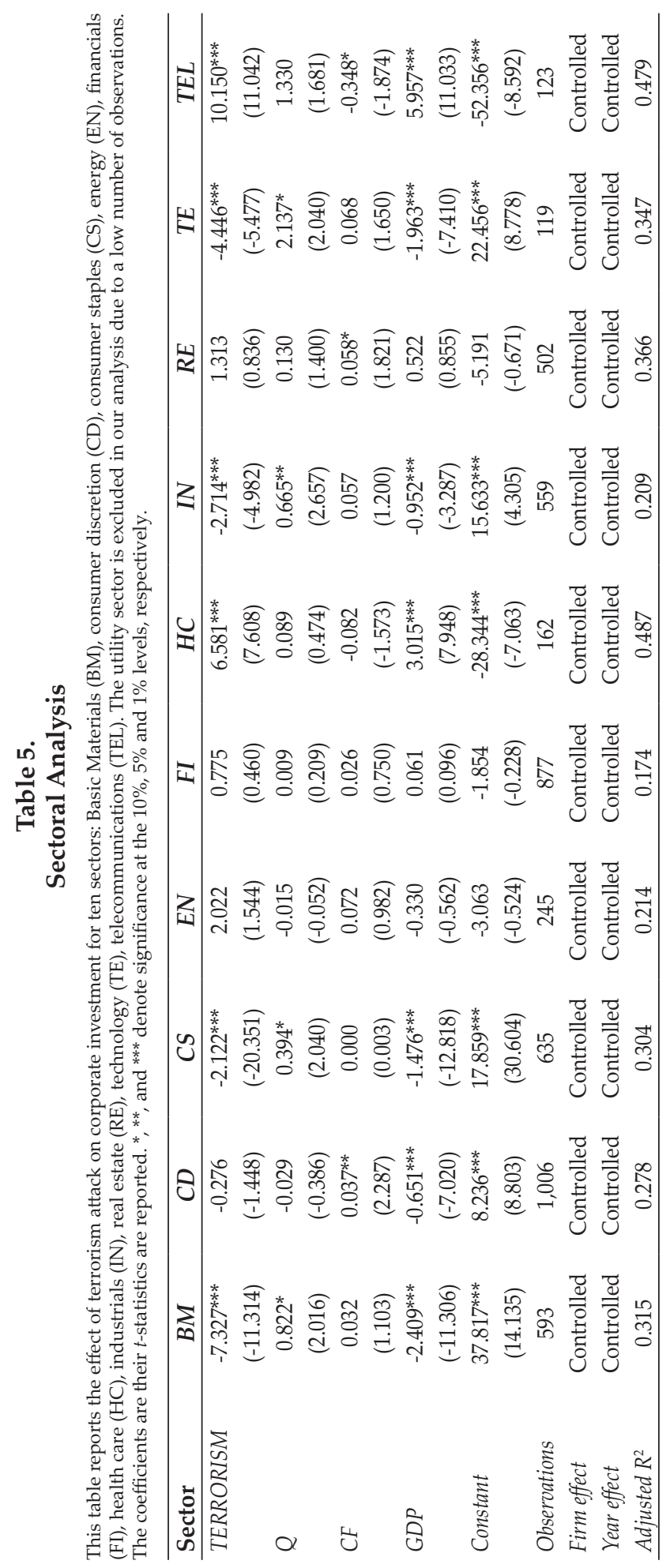




\section{B3. Firm Characteristics Analysis}

This section aims to investigate whether firms with different characteristics react differently to terrorism. Table 6 reports the effect of terrorist attacks on corporate investment for panels sorted on firm characteristics. There are some interesting observations that stand out. First, the coefficient of TERRORISM is statistically significant in eight (80\%) out of 10 panels; the exception are the MV0 and VO1 panels. Like the sectoral analysis, we see heterogeneity in both sign and size of the effect of terrorism on corporate investment across panels. Regarding the sign of terrorism effect on investment, the results show that the capital expenditure of firms with MV1, BM0, FA0, TV1, TV0 and VO0 are affected negatively by an increase in the number of terrorist attacks. In contrast, BM1 and FA1 firms respond positively, i.e. raise capital expenses, to an increase in the number of attacks. Furthermore, among firms which are affected negatively, terrorism has the weakest impact on capital expenditure of TV1 firms: the coefficient is -0.283 , and the strongest impact is on FA1 firms (-2.123). For those firms that react positively to terrorist shocks, the strongest impact is on FA1 firms which is followed by BM1 firms. The values of the TERRORISM coefficient of these two panels are 1.283 and 0.842 , respectively.

Turning to the economic significance results, we find that BM1 and FA1 firms raise their capital expenditure by $13.02 \%$ and $19.83 \%$, respectively, in response to a one standard deviation increase in the number of terrorist attacks. Across MV1, BM0, FA0, TV1, TV0, and VO0 firm panels, firms reduce their capital investment by between $5.91 \%$ to $32.82 \%$ when the number of attacks increases by one standard deviation. The biggest cut in capital expenditure is found for FA0 firms, while the modest cut belongs to TV1 firms.

Finally, consistent with our expectations, the effect of other determinants, namely, $Q, C F$ and GDP, is statistically significant in most of the panels. Moreover, the value of adjusted $R$-squared varies from $23.4 \%$ to $41.7 \%$.

\section{Robustness Tests}

We apply a number of robustness tests. In particular, we use different model specifications as well as different sub-sample to see whether our main results hold.

\section{C1. Different Regression Model Specifications}

We test the consistency of our main findings by adding two control variables, namely the growth rate of sales, GROWTH, and the leverage ratio, LEVERAGE, into our main regression. This approach is also used by An et al. (2016) and Wang et al. (2017). 


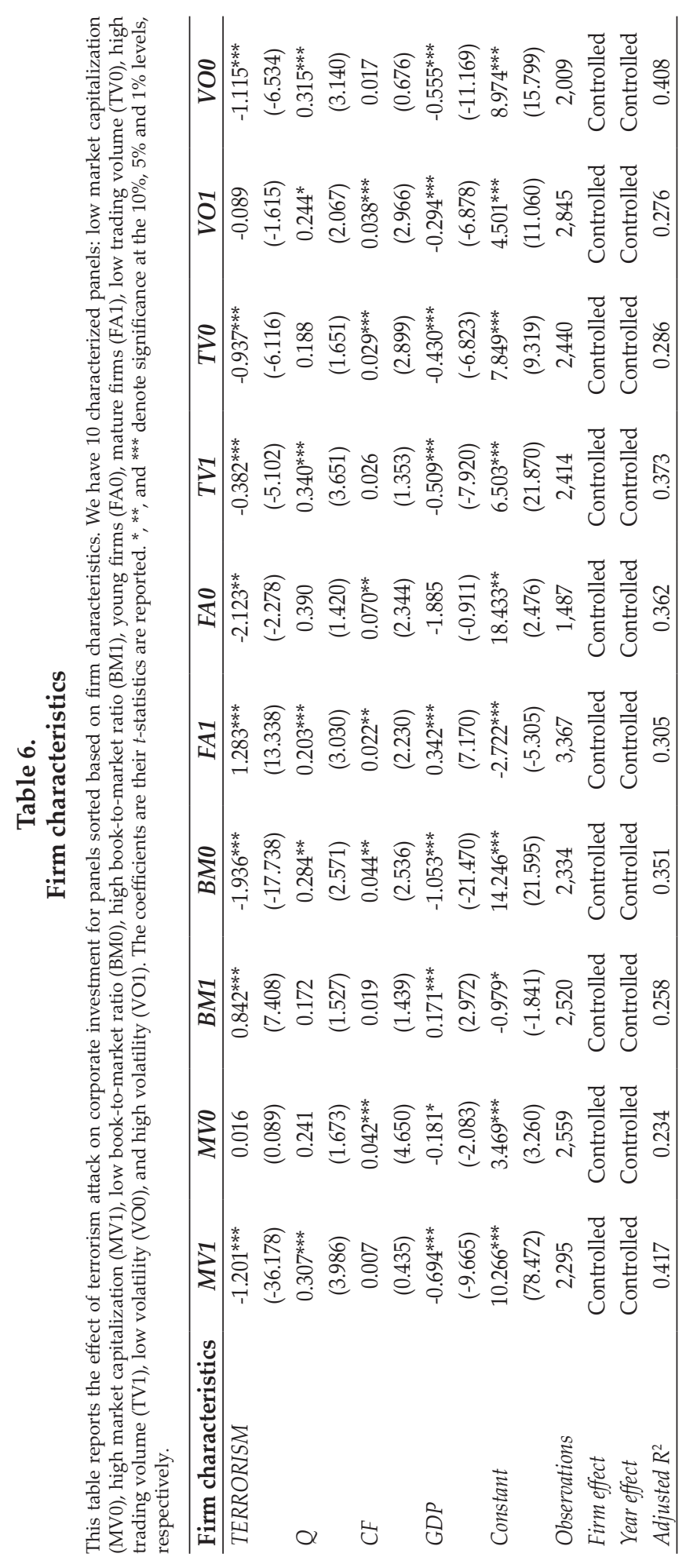


Table 7.

\section{Different regression model specifications}

This table reports the results of the robustness test using different model specifications. We include additional control variables that have been used in previous literature to our baseline regression model. The coefficients are their $t$-statistics are reported. ${ }^{*}, * *$ and ${ }^{* * *}$ denote significance at the $10 \%, 5 \%$ and $1 \%$ levels, respectively.

\begin{tabular}{lccc}
\hline & $\mathbf{( 1 )}$ & $\mathbf{( 2 )}$ & $\mathbf{( 3 )}$ \\
\hline TERRORISM & $-0.391^{* * *}$ & $-0.917^{* * *}$ & $-0.724^{* * *}$ \\
$Q$ & $(-4.706)$ & $(-11.391)$ & $(-8.924)$ \\
& $0.282^{* * *}$ & $0.256^{* * *}$ & $0.277^{* * *}$ \\
CF & $(2.941)$ & $(2.764)$ & $(2.936)$ \\
GDP & $0.026^{* * *}$ & $0.029^{* * *}$ & $0.024^{* * *}$ \\
& $(3.159)$ & $(4.356)$ & $(2.987)$ \\
GROWTH & $-0.237^{* * *}$ & $-0.720^{* * *}$ & $-0.497^{* * *}$ \\
& $(-5.662)$ & $(-12.801)$ & $(-9.703)$ \\
LEVERAGE & 0.003 & & 0.003 \\
& $(0.888)$ & & $(0.777)$ \\
Constant & & $-3.128^{* * *}$ & $-2.760^{* * *}$ \\
& & $(-3.869)$ & $(-3.351)$ \\
Observations & $5.962^{* * *}$ & $8.102^{* * *}$ \\
Firm effect & $5.091^{* * *}$ & $(23.718)$ & $(18.164)$ \\
Year effect & $(10.825)$ & 4,843 & 4,733 \\
Adjusted $R^{2}$ & 4,744 & Controlled & Controlled \\
\hline
\end{tabular}

The regression results are reported in Table 7. Our main findings are consistent. Regardless of the model specifications, terrorism has a negative effect on the level of corporate capital expenditure. Moreover, the coefficient of TERORISM is statistically significant at the $1 \%$ level in all three models.

\section{C2. Different Sub-samples}

In general, financial crises led to a shock to the supply of credit, hence firm investment is affected during these periods (Kahle and Stulz, 2013). Existing literature has shown that corporate investment is significantly affected during the financial crisis (see Rousseau and Kim, 2008; Campello et al., 2011; Kahle and Stulz, 2013; Phan et al., 2019). Thus, in this section, we further our robustness test by employing different sub-samples. In particular, we use three different subsamples: 1999-2007 period; 2008-2017 period; and 1999-2017 period excluding the Global Financial Crisis (2007-2009). 
Table 8.

\section{Different Sub-samples}

This table reports the results of the robustness test using different sub-samples. We divide our sample into two subsample periods 1999-2007 and 2008-2017. We also have another sub-sample that the Global Financial Crisis period 2007-2009 is excluded. The coefficients are their $t$-statistics are reported. ${ }^{*}, * *$, and ${ }^{* * *}$ denote significance at the $10 \%$, $5 \%$ and $1 \%$ levels, respectively.

\begin{tabular}{lccc}
\hline & $\mathbf{1 9 9 9 - 2 0 0 7}$ & $\mathbf{2 0 0 8 - 2 0 1 7}$ & Remove 2007-2009 \\
\hline TERRORISM & $-0.245^{* *}$ & $-1.575^{* * *}$ & $-0.635^{* * *}$ \\
$Q$ & $(-3.278)$ & $(-17.464)$ & $(-6.631)$ \\
CF & 0.225 & $0.250^{*}$ & $0.287^{* *}$ \\
& $(1.538)$ & $(2.123)$ & $(2.781)$ \\
GDP & 0.021 & 0.021 & $0.033^{* * *}$ \\
& $(1.443)$ & $(1.606)$ & $(4.374)$ \\
& 0.103 & $1.653^{* * *}$ & $-0.461^{* * *}$ \\
Constant & $(1.315)$ & $(10.265)$ & $(-10.896)$ \\
& $4.848^{* * *}$ & -0.178 & $7.007^{* * *}$ \\
Observations & $(6.783)$ & $(-0.186)$ & $(14.024)$ \\
Firm effect & $-0.245^{* *}$ & $-1.575^{* * *}$ & $-0.635^{* * *}$ \\
Year effect & 1,591 & 3,263 & 4,079 \\
Adjusted $R^{2}$ & Controlled & Controlled & Controlled \\
\hline
\end{tabular}

The results of this robustness test are reported in Table 8. Similar to previous findings, the effect of terrorist attacks on the level of corporate investment remains statistically significant and negative across all three sub-samples. Therefore, we can safely conclude that the choice of different sub-samples does not influence the effect of terrorism on the level of firm capital expenditure.

\section{CONCLUDING REMARKS}

This paper tests the effect of terrorism on corporate investment in Indonesia. The empirical analysis is based on an annual frequency data set, which includes around 5000 observations from 1997 until 2017. Applying the standard investment type regression that is used widely in the literature, the paper offers some important findings. First, the effect of terrorist attacks on corporate investment in the aggregate panel is negative. On average, with a one standard deviation increase in the number of attacks, firms' capital expenditure reduces by $9.23 \%$. Second, firms in different sectors react differently to terrorist shocks. A one standard deviation increase in the number of terrorist attacks causes the level of corporate investment to change from $-113.27 \%$ to $156.91 \%$ across different sectors. Third, similar heterogeneity is found when we divide our sample into different panels based on firm characteristics. Using firm characteristic sampling, the economic significance of a one standard deviation increase in terrorist attacks on firm investment is in the $-5.91 \%$ to $19.83 \%$ range. Finally, results from our robustness tests are similar to our baseline findings. 


\section{REFERENCES}

Abadie, A., \& Gardeazabal, J. (2003). The Economic Cost of Conflict: A Case Study of the Basque Country. American Economic Review, 93, 113-132.

Agung, J. (2000). Financial Constraint, Firms' Investment and the Channels of Monetary Policy in Indonesia. Buletin Ekonomi Moneter dan Perbankan, 3, 146178.

Al-Awadhi, A.M., Al-Saifi, K., Al-Awadhi, A., \& Alhamadi, S. (2020). Death and Contagious Infectious Diseases: Impact of the COVID-19 Virus on Stock Market Returns. Journal of Behavioral and Experimental Finance, 100326.

Ali, M., Alam, N., \& Rizvi, S.A.R. (2020). Coronavirus (COVID-19) - An Epidemic or Pandemic for Financial Markets. Journal of Behavioral and Experimental Finance, 100341.

An, H., Chen, Y., Luo, D., \& Zhang, T. (2016). Political Uncertainty and Corporate Investment: Evidence from China. Journal of Corporate Finance, 36, 174-189.

Arin, P. K., Ciferri, D., \& Spagnolo, N. (2008). The Price of Terror: The Effects Of Terrorism On Stock Market Returns and Volatility. Economic Letters, 101, 164167.

Bernanke, B. (1983). Irreversibility, Uncertainty, and Cyclical Investment. Quarterly Journal of Economics, 97, 85-106.

Blomberg, S.B., Hess, G.D., \& Orphanides, A. (2004). The Macroeconomic Consequences of Terrorism. Journal of Monetary Economics, 51, 1007-1032.

Bloom, N. (2009). The Impact of Uncertainty Shocks. Econometrica, 77, 623-685.

Bloom, N., Bond, S., \& Van Reenen, J. (2007). Uncertainty and Investment Dynamics. Review of Economic Studies, 74, 391-415.

Blundell, R., Bond, S., Devereux, \& M., Schiantarelli, F. (1992). Investment and Tobin's Q: Evidence from Company Panel Data. Journal of Economics, 51, 233257.

Blundell, R., Griffith, R., \& Reenen, J. (1999). Market Share, Market Value and Innovation In A Panel Of British Manufacturing Firms. Review of Economic Studies, 66, 529-554.

Bradsher, K., \& Banerjee, N. (2002). Terror in Bali: The Economic Cost; Indonesia Stocks Fall 10\%; Others in Asia Off Modestly; Severe Tourism Losses Seen. The New York Times, Section A, 12.

Burch, T., Emery, D., \& Fuerst, M. (2003). What Can “Nine-Eleven” Tell Us About Closed-End Fund Discounts and Investor Sentiment? The Financial Review, 38, 515-529.

Campello, M., Giambona, E., Graham, J.R., \& Harvey, C.R. (2011). Liquidity Management and Corporate Investment during A Financial crisis. The Review of Financial Studies, 24, 1944-1979.

Carter, D., \& Simkins, B. (2004). The Market's Reaction to Unexpected, Catastrophic Events: The Case of Airline Stock Returns and the September 11th Attacks. Quarterly Review of Economics and Finance, 44, 539-558.

Chesney, M., Reshetar, G., \& Karaman, M. (2011). The Impact of Terrorism on Financial Markets: An Empirical Study. Journal of Banking and Finance, 35, 253267.

Choyakh, H. (2008). A Model of Tourism Demand for Tunisia: Inclusion of the Tourism Investment Variable. Tourism Economics, 14, 819-838. 
Devpura, N. (2020). Can Oil Prices Predict Japanese Yen? Asian Economics Letters, 1. https://doi.org/10.46557/001c.17964

Drakos, A.K. (2004). Terrorism-Induced Structural Shifts in Financial Risk: Airline Stocks in the Aftermath of The September 11th Terror Attacks. European Journal of Political Economy, 20, 435-446.

Eckstein, Z., \& Tsiddon, D. (2004). Macroeconomic Consequences of Terror: Theory and The Case of Israel. Journal of Monetary Economics, 51, 971-1002.

Elder, J., \& Serletis, A. (2010a). Oil Price Uncertainty. Journal of Money, Credit and Banking, 42, 1137-1159.

Elder, J., \& Serletis, A. (2010b). Oil Price Uncertainty in Canada. Energy Economics, 31, 852-856.

Eldor, R., \& Melnick, R. (2004). Financial Markets and Terrorism. European Journal of Political Economy, 20, 367-386.

Enders, W., \& Sandler, T. (1996). Terrorism and Foreign Direct Investment in Spain and Greece. KYKLOS, 49, 331-352.

Fang, X., \& Zhang, Y. (2021). An Analysis of the Dynamic Asymmetric Impact of the COVID-19 Pandemic on the RMB Exchange Rate. Asian Economics Letters, 1. https://doi.org/10.46557/001c.18644

Frey, B., Luechinger, S., \& Stutzer, A. (2007). Calculating Tragedy: Assessing the Costs of Terrorism. Journal of Economic Surveys, 21, 1-24.

Fu, M., \& Shen, H. (2020). COVID-19 and Corporate Performance in The Energy Industry. Energy Research Letters, 1, 12967.

Gil-Alana, L. A., \& Monge, M. (2020). Crude Oil Prices and COVID-19: Persistence of the shock. Energy Research Letters, 1, 13200.

Gilchrist, S., Sim, J.W., \& Zakrajšek, E. (2014). Uncertainty, Financial Frictions, and Investment Dynamics (NBER Working Papers 20038). National Bureau of Economic Research.

Glaser, M., \& M. Weber. (2005). September 11 and Stock Return Expectations of Individual Investors. Review of Finance, 9, 243-279.

Goel, S., Cagle, S., \& Shawky, H. (2017). How Vulnerable are International Financial Markets to Terrorism? An Empirical Study Based on Terrorist Incidents Worldwide. Journal of Financial Stability, 33, 120-132.

Greenwald, B.C., \& Stiglitz, J.E. (1990). Macroeconomic Models with Equity and Credit Rationing. In Asymmetric Information, Corporate Finance, and Investment. University of Chicago Press, 15-42.

Gulen, H., \& Ion, M. (2015). Policy Uncertainty and Corporate Investment. Review of Financial Studies, 29, 523-564.

Haroon, O., \& Rizvi, S.A.R. (2020). COVID-19: Media Coverage and Financial Markets Behavior - A Sectoral Inquiry. Journal of Behavioral and Experimental Finance, 100343.

Henriques, I., \& Sadorsky, P. (2011). The Effect of Oil Price Volatility on Strategic Investment. Energy Economics, 33, 79-87.

Hidayat, R. (2010). Investment Decision and Financial Constraints: Empirical Study on Indonesian Stock Exchange. Buletin Ekonomi Moneter Dan Perbankan, 12, 425-446.

Hoang, T. H. V., \& Syed, Q. R. (2021). Investor Sentiment and Volatility Prediction of Currencies and Commodities during the COVID-19 Pandemic. Asian Economics Letters, 1. https://doi.org/10.46557/001c.18642 
Ito, H., \& Lee, D. (2005). Assessing the Impact of The September 11 Terrorist Attacks On U.S. Airline Demand. Journal of Economics and Business, 57, 75-95.

Johnston, B., \& Nedelescu, O. (2006). The Impact of Terrorism on Financial Markets. Journal of Financial Crime, 13, 7-25.

Julio, B., \& Yook, Y. (2011). Political Uncertainty and Cross-Border Flows of Capital (Working Paper). London Business School.

Julio, B., \& Yook, Y. (2012). Political Uncertainty and Corporate Investment Cycles. Journal of Finance, 67, 45-83.

Kahle, K.M., \& Stulz, R.M. (2013). Access to Capital, Investment, and the Financial Crisis. Journal of Financial Economics, 110, 280-299.

Karolyi, G.A., \& Martell, R. (2005). Terrorism and the Stock Market (Working Paper). Ohio State University.

Liu, L., Wang, E. Z., \& Lee, C. C. (2020). Impact of the COVID-19 Pandemic on the Crude Oil and Stock Markets in the US: A Time-Varying Analysis. Energy Research Letters, 1, 13154.

Llussa, F., \& Tavares, J. (2011). Which Terror at Which Cost? On The Economic Consequences of Terrorist Attacks. Economic Letters, 110, 52-55.

McDonald, R., \& Siegel, D. (1986). The Value of Waiting to Invest. Quarterly Journal of Economics, 101, 707-727.

Mohn, K., \& Misund, B. (2009). Investment and Uncertainty in the International Oil and Gas Industry. Energy Economics, 31, 240-248.

Narayan, P. K. (2020a). Oil Price News and COVID-19-Is There Any Connection? Energy Research Letters, 1, 13176. https://doi.org/10.46557/001c.13176

Narayan, P. K. (2020b). Did Bubble Activity Intensify During COVID-19? Asian Economics Letters, 1. https://doi.org/10.46557/001c.17654

Narayan, P. K. (2020c). Has COVID-19 Changed Exchange Rate Resistance to Shocks? Asian Economics Letters, 1. https://doi.org/10.46557/001c.17389

Narayan, P.K., Narayan, S., Khademalomoom, S., \& Phan, D.H.B. (2018). Do Terrorist Attacks Impact Exchange Rate Behavior? New International Evidence. Economic Inquiry, 56, 547-561.

Narayan, P.K., Phan, D.H.B., \& G., Liu (2021). COVID-19 Lockdowns, Stimulus Packages, Travel Bans, and Stock Returns. Finance Research Letter, 38, 101732.

Nikkinen, J., \& Vahamaa, S. (2010). Terrorism and Stock Market Sentiment. The Financial Review, 45, 263-275.

Nitsch, V., \& Schumacher, D. (2004). Terrorism and International Trade: An Empirical Investigation. European Journal of Political Economy, 20, 423-433.

Oh, C. H., \& Oetzel, J. (2011). Multinationals' Response to Major Disasters: How Does Subsidiary Investment Vary in Response to The Type of Disaster and The Quality of Country Governance? Strategic Management Journal, 32, 658-681.

Phan, D.H.B., \& Narayan, P.K. (2020). Country responses and the Reaction of The Stock Market to COVID-19-A Preliminary Exposition. Emerging Markets Finance and Trade, 56, 2138-2150.

Phan, D.H.B., Tran, V.T., \& Nguyen, D.T. (2019). Crude Oil Price Uncertainty and Corporate Investment: New Global Evidence. Energy Economics, 77, 54-65.

Pindyck, R.S. (1988). Irreversible Investment, Capacity Choice, and the Value of the Firm. American Economic Review, 78, 969-998. 
Pindyck, R.S. (1991). Irreversibility, Uncertainty, and Investment. Journal of Economic Literature, 29, 1110-1148.

Qin, M., Zhang, Y. C., \& Su, C. W. (2020). The Essential Role of Pandemics: A Fresh Insight into the Oil Market. Energy Research Letters, 1, 13166.

Rousseau, P.L., \& Kim, J.H. (2008). A Flight to Q? Firm Investment and Financing in Korea Before and After the 1997 Financial Crisis. Journal of Banking E Finance, $32,1416-1429$.

Setiastuti, S. (2017). Time-Varying Macroeconomic Impacts of Global Economic Policy Uncertainty to A Small Open Economy: Evidence from Indonesia. Buletin Ekonomi Moneter Dan Perbankan, 20, 129-148.

Sha, Y., \& Sharma, S. S. (2020). Research on Pandemics Special Issue of the Journal Emerging Markets Finance and Trade, 56, 2133-2137. https://doi.org/10.1080/1540496X.2020.1795467

Sharma, S.S., \& Sha, Y. (2020). Part A: Special Section on COVID-19 Research. Emerging Markets Finance and Trade, 56, 3551-3553. https://doi.org/10.1080/1540496X.2020.1858617

Sharma, S. S. (2020). A Note on the Asian Market Volatility during the COVID-19 Pandemic. Asian Economics Letters, 1. https://doi.org/10.46557/001c.17661

Singh, P. (2013). Impact of Terrorism on Investment Decisions of Farmers: Evidence from the Punjab Insurgency. Journal of Conflict Resolution, 57, 143-168.

Uri, N.D. (1980). Energy as a determinant of Investment Behavior. Energy Economics, 2, 179-183.

Wang, Y., Xiang, E., Cheung, A., Ruan, W., \& Hu, W. (2017). International Oil Price Uncertainty and Corporate Investment: Evidence from China's Emerging and Transition Economy. Energy Economics, 61, 330-339.

Wang, K.-H., \& Su, C.-W. (2021). Asymmetric Link Between COVID-19 and Fossil Energy Prices. Asian Economics Letters, 1. https://doi.org/10.46557/001c.18742

Zhang, D., Hu, M., \& Ji, Q. (2020). Financial Market under the Global Pandemic of COVID-19. Financial Research Letter, 36, 101528. 
This page is intentionally left blank 